\title{
The Impact of Dividend Policy on Firm Performance in Public Listed Company in Malaysia
}

Jee Kim Foong, Nurul Izza Abd. Malek

To Link this Article: http://dx.doi.org/10.6007/IJARBSS/v12-i1/11008

DOI:10.6007/IJARBSS/v12-i1/11008

Received: 09 November 2021, Revised: 12 December 2021, Accepted: 29 December 2021

Published Online: 17 January 2022

In-Text Citation: (Foong \& Malek, 2022)

To Cite this Article: Foong, J. K., \& Malek, N. I. A. (2022). The Impact of Dividend Policy on Firm Performance in Public Listed Company in Malaysia. International Journal of Academic Research in Business and Social Sciences, 12(1), $640-660$.

\section{Copyright: @ 2022 The Author(s)}

Published by Human Resource Management Academic Research Society (www.hrmars.com)

This article is published under the Creative Commons Attribution (CC BY 4.0) license. Anyone may reproduce, distribute, translate and create derivative works of this article (for both commercial and non0-commercial purposes), subject to full attribution to the original publication and authors. The full terms of this license may be seen at: http://creativecommons.org/licences/by/4.0/legalcode

\section{Vol. 12, No. 1, 2022, Pg. $640-660$}

Full Terms \& Conditions of access and use can be found at http://hrmars.com/index.php/pages/detail/publication-ethics 


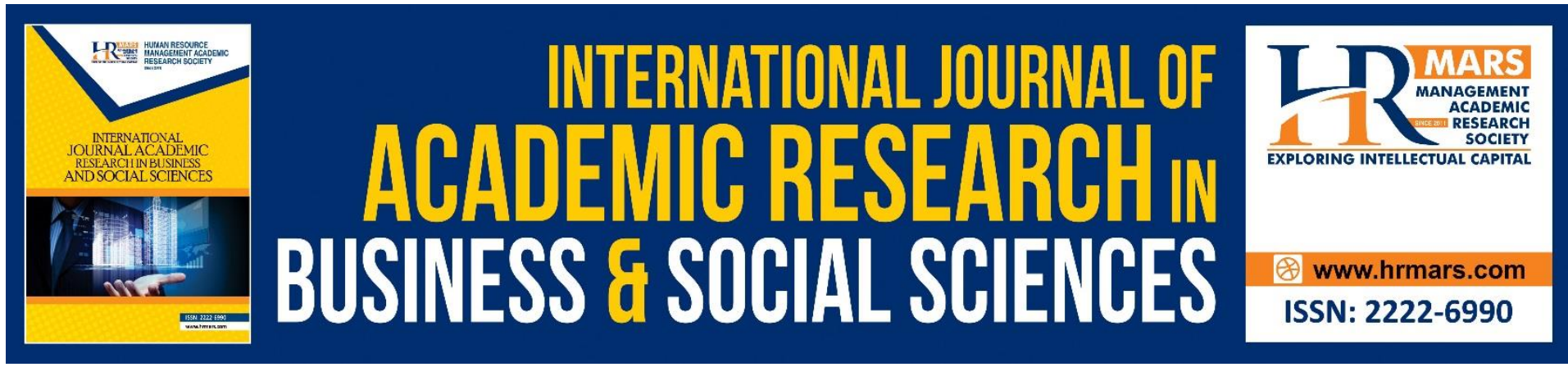

\title{
The Impact of Dividend Policy on Firm Performance in Public Listed Company in Malaysia
}

\author{
Jee Kim Foong, Nurul Izza Abd. Malek \\ Faculty of Economics and Business, Universiti Malaysia Sarawak (UNIMAS) \\ Email: amnizza@unimas.my
}

\begin{abstract}
The aim of this study is to investigate the relationship between dividend policy and firm performance in Public listed company in Malaysia. The sample collected for this study covered 8 years from 2011 to 2018. This study will focus one of the subsectors from consumer product and service sector which listed in Bursa Malaysia. The total observation was 200. This study used two measurements for firm performance which are return on equity (ROE) and return on asset (ROA). The measurement of dividend policy is earning per share (EPS), dividend payout ratio (DPR) and price earnings ratio (PER). Based on the findings, there is significant relationship between EPS with ROE and ROA. For PER, there is an insignificant relationship with ROE but it has significant relationship with ROA. However, DPR has insignificant relationship with ROE and ROA. The result from this study will brings advantage and usefulness for investor as well as policy marker for in Malaysia because it provides better understandings and knowledge on dividend policy on firm performance for consumer product and service sector in Malaysia.
\end{abstract}

Keywords: Dividend Policy, Firm Performance, Earnings Per Share, Dividend Pay-Out Ratio, Price Earnings Ratio

\section{Introduction}

Recently, the Malaysian financial market has remained stable and continues to work effectively throughout an unpredictable global economic environment of the Covid-19 disease outbreak. Financial markets are assumed as a core and vital component and are the primary means of communication between businesses and consumers of accounting information. Economic growth is helped by investors who mobilise savings and turn it into investments. This provides the economy with a stable foundation. As stated by Khan et al (2016) that the attractiveness of dividend policy increased in recent years. This increases due to the investors preferred a firm that does released dividend to the public as it gives a promising return to investors on their investment. Globally, people believe that dividend policy has a substantial effect on firm performance.

Firm performance is defined by way of how good a firm is in enhances the wealth of shareholder and efficiency of a firm to generate income from the shareholder investment (Ajanthan, 2013). This is because the key goal of firm is to enhance the shareholders wealth 
and making profit (Pandey, 2003). It is their priorities to ensure that the shareholders receive a good compensation for their investment. Other than that, as stated by Azhagaiah and Priya (2008), shareholder wealth is primarily affected through revenue growth, margin of profit development, capital allocation decisions and capital structure decisions. Therefore, dividend policy would affect the firm value and shareholder wealth.

Consequently, dividend policy is one of the most critical investment choices made by corporate managers (Baker \& Powell, 1999). This is because they decide the funds flow to the investors and the funds the investment company retains. Uwuigbe et al (2012) also argued that dividend policy remains one of the most significant financial policies used for company and also for government, consumers, employees, and shareholders. Firm that able to pay their shareholders dividends give a positive message about the performance of company. If a company choose not to pay or pay less dividends, it will increase its more internal earnings, and reduce the dependency on external earnings. In contrast, if a firm choose to pay high dividends, it would result in few internal earnings, thus raising firm's reliance on debt and other external funding (Yusof \& Ismail, 2016).

The company usually release the dividend at year end and would decide either to pay as a dividend or reinvested as retained earnings for the company. The dividend can pay out in the form of shares split, cash dividends, share buybacks and stock dividend. Shareholders and management have different opinion on the firm's dividend policy. The shareholders chose to distribute their profits as a dividend, while the management would prefer to allocate less dividend to the shareholders and to maintain a greater portion of the business for future development and investment. This will lead to agency theory. Theoretically, it focused on the conflict of interest between the shareholders and management (Jensen \& Meckling, 1976). The primary role of manager is to maximise shareholder wealth and run the business appropriately. The agency problems can arise when there is a surplus cash flow in the company and manager have to invest it in the project nevertheless, they invest the money in their own interests rather than the interests of shareholders. Therefore, as a shareholder, they should monitor the managers. The cost on monitoring of managers is known as agency cost. To minimizing the agency cost, dividend policy is significant.

The influence of dividend policy is found to be connected with ownership of the firm as well as positive outcomes. Consequently, the function of dividend policy supports the firm's activities to perform well and recognize it in the financial environment. Dividend strategy is a desirable route to effective financial results. Dividend payment may also give a signal about the value of the business for other potential investors (Allen \& Rachim, 1996). The decision of paying the dividend will affect the firm's earnings. Moreover, the dividend would usually be paid out of a portion of earnings after taking into account the remaining earnings. Paying out the dividend does reflect the company's ability to manage equity and debt (Mat et al., 2017). By identifying the capability of paying dividends, investors and shareholders will prefer to invest in the firm. In addition, dividend policies may be used to mitigate the expenses of the agency. Given that management's accomplishment can be calculated by the shareholder capital, management have to fully understand dividend policy (Farrukh et al., 2017).

\section{Background of Study}

Dividend policy remains one of the top ten puzzles in finance. Dividend policy defined as the rules and regulation used by company to decide the payment of dividend to shareholders (Nissim \& Ziv, 2001). Dividend policy decision is essential as it forecast the 
amount of funds transferred to investors and firm's retained earnings for future investment. Dividend policy also delivers information for stakeholders about the performance of the company. Dividend decision is primary aspect of corporate as it is essentially the gain of shareholders and it decided by various factors in a company such as funding constraints, firm size, pressure from shareholders, investment opportunities and choices and regulatory schemes. Therefore, there are many ways for the firm to distribute profits to shareholders such as cash dividends, shares split, share buybacks and stock dividend. Among many ways, cash dividend is the most desirable because the dividend is directly transfer to the shareholder (Wong, 2012). Besides, the dividend company of firm are not the only source of cash flow to shareholders but also provide insight on the success of the company.

The Board of Directors of the company is accountable for agreeing about how much the revenue is allocated to the shareholders as a reward for investment and risk-taking and how much the company keeps as retained earnings. Truthfully, the companies typically have two options on raising funds for their investments or ventures which can classified as internal sources and external sources. Internal sources would be depending on revenue or accumulated earnings, while external sources would be new credit and borrowing or selling new shares to the public. Issue new shares are a popular way for businesses to grow their business without the assistance of financial institutions' loans (May \& Yacob, 2018). When investors buy the stock of the company, it increases the available internal cash of the company as well increases the capital of the company. This rise in cash flows encourages the company to invest in further projects to increase the potential cash flows of the company.

The dividend decision is critical for firms since it decides which investor funds flow and which investment funds the company keeps. The dividend policy may also provide stakeholders with details on the success of the business. The investments made by a business decide future profits and dividends; and the dividend policy affects capital costs as these connected decisions are taken, with the intention of optimising shareholder wealth. Earnings per share (EPS) also plays important role which it gives information about the ability of the firm to generate the profit. It refers to the distribution of the profit to average outstanding of the shareholders. The value of the share will give effect on firm performance. This is because the earning per share was act as market value of shares of company ( $\mathrm{Nabi}, 2014)$.

In Malaysia, there are no rules and guidelines for the standard of dividend policy (Subramaniam \& Devi, 2010). In other words, corporations are free to make decisions on the payment of dividends to their shareholders. The distribution of dividend decided by the firm must comply with the Company Act 1965. There are several sectors of company listed in Bursa Malaysia. One of the sectors listed is consumer product and service sector. The consumer goods business is the organisation that produces and sells products for direct use for its own use and enjoyment by the consumers.

According to Fernando (2020), companies in the utilities and consumer staple sectors also have higher dividend yields. Bank Negara Malaysia has announced a dividend payment of RM3 billion to the government for 2015. Hence, this research will concentrate on the impact of dividend policy on firm performance in public listed firm which is consumer products sector.

There are few researchers conduct the study on this topic. Lai (2016) had studied about the effect of dividend policy on financial performance in Malaysia. The researchers had focus on two sector which are consumer products and trading. The firms in consumer products and trading sector were random selected from Bursa Malaysia and the study period is 10 years. The findings show that the effect of the dividend policy on the firm output of the 
consumer goods sector has a greater impact relative to the trading sector. This shows that different sector would give different level of effect on firm performance. The study also suggested the return on equity can be used as measurement of firm performance in the future where the return on equity is one of the measurements adopted in this research.

Furthermore, there are also many researchers who have conducted a study on dividend policy and firm performance in other country for example, Pakistan, Nigeria. There are less researcher conducts the study regarding the impact of dividend policy on firm performance in our country which is Malaysia. As the problem if dividend policy is still unsolved, the outcome of dividend policy of different countries is significant. Previous studies conducted by the other researcher is only focus on particular sector. Other than that, management has faced a huge dilemma in dividends sharing across the world. This is because the issue of dividend policy in corporate entities in both developed and developing countries has been of great global concern. Both public and private limited companies have a tough choice to assess the acceptable amount of dividend payment to shareholders and to decide whether or not to give non-cash alternatives (Ekene et al., 2019). Therefore, this study will focus on consumer product and services sector and these papers bring up the awareness to the reader on the impact of dividend policy on firm performance in public listed company in Malaysia.

\section{Problem Statement}

According to Hafeez and Attiya (2009), dividend policy is still one of the most debatable topics and it had been mystery in corporate finance for a long time. Dividend policy is still common in developed and emerging markets. The mystery had brought to few conflicts not only in theoretical but also in empirical research in order to explain the reason on why company choose to pay or why company do not pay dividends. Numerous theories developed to assess the relationship between dividend policy and firm value, but there is still no conclusion on it.

Dividend irrelevance theory is the most famous studies developed by (Miller and Modigliani, 1961). The study had become benchmark for other researchers to create models on dividend actions of firm value and to guide the managers to set up corporate pay- out policies. According to the dividend irrelevance theory, it discussed that the dividends is not relevant with the valuation of the company. Not only that, the value of the firm is only driven by potential earnings and the risk of the investments. Instead of capital gains, investors will have to pay high taxes on dividends. This shows that once their shares are sold in public, investor will be taxed. A dividend-free business would draw investors more than a dividendpaying company (Black, 1976). There is a gap exist between the dividend irrelevance theory with dividend policy on firm performance. This theory is revoked by the research of Hafeez et al (2018) who stated that between dividend policy on firm performance, it has impact on each other. Furthermore, Kanakriyah (2020) stated that the current research still attempting to eliminate these ambiguities and examine the dividend policy effect on financial performance of company in emerging economies. Although there are many studies conducted in this topic before, it is important to have a study on this topic in Malaysia. Hence, to fill up the gap, this research will further study on whether there is a relationship between dividend policy and firm performance among listed companies of consumer food and service in Malaysia. 


\section{Research Question}

The general objective of this study is to examine on the impact of dividend policy on firm performance in public listed company in Malaysia. The specific objective of this study are as follows:

i. To examine the relationship between earnings per share and firm performances in public listed company in Malaysia.

ii. To investigate the dividend pay-out ratio and firm performance in public listed company in Malaysia.

iii. To investigate the price earnings ratio and firm performance in public listed company in Malaysia.

\section{Literature Review \\ Empirical Evidence}

Khan (2018) who studied on the effect of dividend policy on the firm performance in Pakistan from the year of 2012 to 2016 by using the method of ordinary least square. There are 9 cement companies was selected in their study. Dividend per share, earning per share, firm size and leverage are used to measure dividend policy while return on equity have been used to measure the firm performance. They observed that the cement sector in Pakistan has a significant positive relationship between earnings per share and return on equity. However, there was an insignificant relationship between dividend per share financial leverage with the return on equity. Firm size has significant relationship with return on equity.

Velnampy, Nimalthasan and Kalaiarasi (2014) investigated on the dividend policy and firm performance for manufacturing companies. The researchers had selected 25 manufacturing companies listed on Colombo stock exchange from the year of 2008 to 2012. The method used was correlation and regression analysis. In the study, the independent variable used is earning per share and dividend pay-out, while return on asset and return on equity is the dependent variable used. Their result showed that the earning per share and dividend pay-out ratio was insignificantly correlated with the firm performance such as return on asset and return on equity.

Narang (2018) had examined the relation between the dividend pay-out and financial performance among listed firm in National stock exchange (NSE) from year 2012 to 2017. The method adopted in the study was correlation and regression analysis. The measurement used for dividend policy was earning per share, dividend pay-out ratio and price earnings ratio while the measurement of firm performance in the study was return on equity and return on asset. The research found that the earning per share, dividend pay-out ratio and price earnings ratio does not correlate with return on equity and return on asset.

A related study by Ugwu, Onyeka and Okwa (2020). The researchers conducted the study for consumer good firms in Nigeria on dividend policy and corporate financial efficiency. The period of the study was from year 2015 to 2019. Besides that, they had selected 10 consumer foods firm which listed under National Stock Exchange and the method used are ordinary least square and correlation matrix. The measurement for dividend policy are dividend pay-out ratio (DPR), dividend per share (DPS) and earnings per share (EPS) while the measurement for firm performance is return on equity (ROE). Firm size (FSZ) and financial leverage (FLV) were used as control variable. Based on the result that presented in the article, the researcher found that DPS has statistically significant relationship with return on equity. The variable such as DPR, EPS, FSZ have statistically insignificant relation with return on 
equity. However, there is negative and insignificant relationship between FLV with return on equity.

Another study on dividend policy and firm performance in Sri Lanka manufacturing firm was conducted by Anandasayanan and Velnampy (2016). The time period chosen of the study was from 2009 to 2014 . The method used to conduct the study was regression analysis. Dividend pay-out ratio and dividend yield were selected as proxy of dividend policy while the return on asset and return on equity were selected as proxy of firm performance. The findings revealed that the dividend policy of the firm have a significant impact on corporate profitability.

Musa et al (2020) had examine the impact of dividend policy on financial performance of consumer goods companies in Nigeria for 8 years which is from year 2010 to 2017. There are 13 consumer firms selected as sample in the study. The researcher had use multiple regression analysis to conduct their study. The proxy of dividend policy are dividend payout and dividend per share while the proxy used for firm performance are return on equity and return on asset. The result shows that dividend per share have a significant positive with return on assets while it has insignificant positive relationship with return on equity. Dividend pay-out have insignificant negative relationship with return on assets but it has insignificant positive relationship with return on equity.

Kajola and Adewumi (2015) conducted a study which examine the relationship between dividend pay-out policy and financial performance of the firm. There are 25 nonfinancial firms was selected as the sample of the study. The period of the study is 10 years which is from year 2004 to 2013. Panel data methodology was employed and Pooled ordinary least square (OLS) was used to estimate the coefficient of the variable. In the study, return on assets is the dependent variable while dividend pay-out ratio is the only independent variable. The findings revealed that there is a significant positive relationship between the variables.

Ogbuagu (2020) studied on the impact of dividend policy on performance of healthcare sector firm. The researcher had selected 9 firms as the sample and the period of study was from year 2014 to 2018. In the study, the proxy for dividend policy are dividend per share, dividend cover, dividend pay-out and dividend yield while return on equity was the proxy of firm performance. Regression model was employed in the study. The findings showed that independent variable used in the study has positive significant relationship with the dependent variable.

\section{Theoretical Review \\ Dividend Irrelevance Theory}

The dividend irrelevance theory of Miller and Modigliani (1961) established the basis of the modern theory. They stated that the dividend policy is not relevant for the cost of capital and the valuation of the firm without taxation or transaction costs. They have shown that their anticipated return on the stock of the company would be invariant if investors were able to generate income by selling and buying the shares, as the company pays its dividends and new share issues (Amidu, 2007).

As dividend policy decisions do not have an impact on the company's assets, investment prospects, anticipated future free cash flows or capital expenditure, the value of the stock is not affected by any adjustment in the corporate pay-out pattern. Therefore, the use of dividend policy is irrelevant and firm may select payment pattern without affect its value. $M \& M$ also suggested that dividend payment will fluctuates as a by-product of the 
investment of the firm and funding decisions (Amidu, 2007). This will not indicate a systematic trend over the time.

Miller and Modigliani (1961) have argued that the worth of the firm is decide only by its basic earning power and corporate risk. However, some assume that the ideal situation of Miller and Modigliani is hypothetical situation and does not exists because the factors such as transactions cost, inflation, taxes and bankruptcy cannot be ignored (Chauhan, Ansari, Taqi \& Ajmal, 2019). A study conducted by the Al Shabibi and Ramesh (2011) shows that the dividend policy is important as it can influence the company's performance. The researcher conducts the study on the determinants of dividend policy and they had divided the factors into two parts include the factors of corporate governance and firm characteristics. In the study, they found that the firm size, probability and cash flow has positive relationship with the dividend policy decision. The size of a corporation is expected to be an appropriate determinant of the company's decision to pay its shareholders dividends, whereas profitability refers to the company's ability to produce profit. The dividend payment of the firm is depending on earning of the firm (Baker and Powell, 2000). When the company choose to pay dividend, the cash flow in the company would be less. Therefore, it would influence the performance of the firm.

\section{Clientele Effect}

Clientele effects indicated that the dividend policy decisions made by firm impact investor differently. Some investors prefer companies that pay substantial sums of profits in the form of dividends, whereas other groups may prefer companies with high retained profits. The distinct tax on dividends and capital gains is essential for the investors behaviours towards dividends and capital gains (Kajola et al., 2015).

Besides, according to Amidu (2007), the clientele effect gives an alternative justification, at least it comes to valuation for the irrelevance of dividend policy. When investors switch to businesses that pay dividends that meet their needs, the dividend policy does not affect the valuation of the company. It is also not appropriate to penalise a company that pays no or low dividends because the owner does not want dividends, while a company that pays high dividends does not have a lower value because investors want dividends. This shows that in any dividend clientele, there are more than enough investors to allow companies to be fair value, regardless of their dividend policy.

\section{Bird in Hand Theory}

Bird in hand theory implies there is a correlation between firm value and dividend payment. Dividends and capital gains were seen differently from bird in hand principle because of market imperfections and volatility. Dividends and capital gains were seen differently because of imperfect markets and uncertainty from the theory of bird in hand. This theory said investors preferred the bird in hand, which refers to the two-in-the-bush cash dividend as potential capital gains endorsed in 1962 by John Litner and in 1963 by Myron Gordon.

Gordon (1963) concluded that the payment of the current dividend reduces the uncertainty of the investor. Investors will now choose a certain amount of revenue instead of the prospect of a higher, but less certain, future gain (Duke et al., 2015). According to Amidu (2007), investors prefer dividends compare to capital gains because the dividends have lower risk than capital gains, firms can create a high dividend payment ratio and provide a high dividend return to maximize the stock price of the investor. 


\section{Methodology \\ Data and Sample}

The data used in this study is gathered from the official website of Bursa Malaysia Securities Berhad and other related sources for year 2011 until 2018. Consumer product and services sector are focused in this study. This sector is chosen as it plays an important role in world economy and act as the driving force of the other industries. Besides, it is one of the sectors that provided large sources on gross domestic product (GDP) of many countries. The data consists of a detailed information for the firm. In this study, new firms were excluded and some of the firm also will be exclude due to unavailability of data.

Taking into account of the research, the companies listed in Bursa Malaysia are chosen as sample. In this study, sample has been selected through the 25 firms from 1 main sector which is consumer product and services sector. The data used in this research is secondary data which is available in Bursa Malaysia official website and other related sources. The secondary data is adopted in this study which the data is obtained from the annual report of consumer product and services sector. In short, the data chosen in this study is within 2011 until 2018 which consists of 25 firms from consumer product and service which allow to have 200 observations in this study.

\section{Measurements}

In this study, the measurement for firm performance is return on assets (ROA) and return on equity (ROE). There are three measurement of dividend policy are selected to measure which include earning per share (EPR), dividend payout ratio (DPR) and price earnings ratio (PER).

\section{Return on Assets}

Return on asset (ROA) known as return on investment. ROA calculates the relationship between the net income of company and its total assets. It is an indicator of the company's overall profitability and operating performance in the use of its total assets. It can be said that today, corporate managers are concerned about the efficiency of the use of assets to boost the company results. Besides, the rising pressure of shareholders and the limited funds make it possible for companies to look for the ways to improve asset productivity in order to preserve competitiveness. Therefore, company need to calculate the return on assets properly. The formula of return on asset as follow:

Return on assets $=\frac{\text { Net income }}{\text { Total assets }}$

\section{Return on Equity}

Return on equity (ROE) is known by the dividend of overall shareholder equity as the profits before interest expense for the specific time span. Dividend adjustment provide investor the information of managerial evaluation of the future and existing firm performance and also enable the corporate executives to be aware of managerial conduct (Gunasekarage \& Power 2006). Return on equity determines company performance by showing how much profit a company generates by using the money invested by the shareholders. The return on equity also demonstrates the efficiency of using the resource of the company. It is important for shareholders specifically, who may then decide if the remuneration they receive rewards the risk assumed. The formula of the return on equity is as follow: 
Return on equity $=\frac{\text { Net income }}{\text { Total shareholder's equity }}$

\section{Earnings per Share}

Earnings per share (EPS) is a percentage of the earnings allocated to the average outstanding shareholder (Khan, 2018). Earnings per share are a sign of stability and competitiveness of the firm. It helps to estimate the ability of company to pay its shareholders dividends. It is one the essential measures for calculating the market price of the shares of the company. An increase in the earning of firm indicates the company value increase while a decline in earnings represents a decrease in company value. Therefore, earnings per share is calculated as:

Earnings per share $=\frac{\text { Net income }- \text { dividend on preferred stock }}{\text { Average common shares outstanding }}$

\section{Price Earnings Ratio}

Price earnings ratio (PER) shows how many times the stock price is covered by earnings per share (EPS). This ratio is a significant indicator of risk of company and return profile. It helps the investor to determine whether to buy the stock of the company at certain price or not. Besides, it also estimated that a fast growth company would have a higher price earnings ratio and a risky share with a low PER. The higher ratio is an indicator of investor trust in the future of the business. Companies with low reinvestment criteria are often assumed to have relative higher PER (Chauhan, Ansari, Taqi \&Ajmal, 2019). Price earnings ratio is calculated as:

Price earnings ratio $=\frac{\text { Earning per share }}{\text { Market } \text { price }}$

\section{Dividend pay-out Ratio}

Dividend pay-out (DPR) is the proportion of dividend distribution among the equity shareholders. It measures the relation between shareholder earnings and the dividend paid to them. This ratio also tends to determine the proportion of earnings held for reinvestment or payment of debt by the firm. In short, the dividend pay-out applies to the decisions as to the amount of the dividend pay-out paid by the companies and the proportion of the profits paid to the owners in the form of dividends. (Nwabuisi \& Aseoluwa, 2014). Dividend payout ratio is calculated as:

Dividend payout ratio $=\frac{\text { Dividend per share }}{\text { Earning per share }}$

\section{Model Specification}

In this study, panel regression model is adopted to observe all the variable independently. This study consists of three independent variables included earning per share (EPS), dividend pay-out ratio (DPR) and price earnings ratio (EPS) while return on equity (ROE) and return on asset (ROA) are the dependent variable used to measure firm performance. $A$ model is derived to study the relationship between dividend policy and firm performance as below:

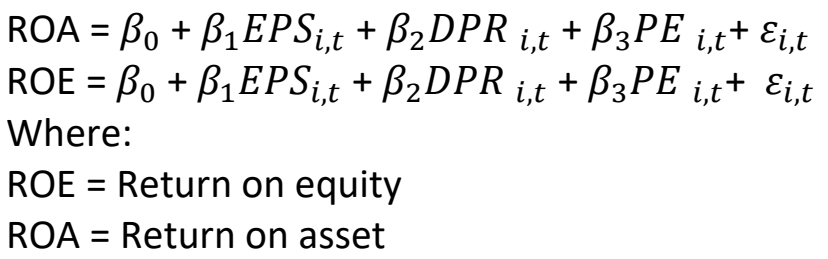


EPS $=$ Earnings per share

DPR $=$ Dividend pay-out ratio

$\mathrm{PE}=$ Price earnings ratio

$\varepsilon=$ error term

$\beta_{0}, \beta_{1}, \beta_{2}, \beta_{3}=$ parameter of the model

\section{Results and Discussion}

Descriptive Statistics

Table 1: Descriptive Statistic

\begin{tabular}{|l|l|l|l|l|l|}
\hline Variables & Observation & Mean & $\begin{array}{l}\text { Standard } \\
\text { Deviation }\end{array}$ & Minimum & Maximum \\
\hline ROE & 200 & 0.20814 & 0.22792 & 0.01847 & 1.22748 \\
\hline ROA & 200 & 0.12418 & 0.08197 & 0.01508 & 0.52512 \\
\hline EPS & 200 & 0.46175 & 0.68358 & 0.01280 & 3.08334 \\
\hline DPR & 200 & 0.60620 & 0.40150 & 0.03117 & 3.15834 \\
\hline PER & 200 & 12.9953 & 8.99288 & 0.02780 & 52.4605 \\
\hline
\end{tabular}

Descriptive statistics shows the estimation of return on equity (ROE), return on assets (ROA), earning per share (EPS), dividend pay-out ratio (DPR) and price earnings ratio (PER). The descriptive statistics generated features the number of observations, mean, standard deviation, minimum and maximum for each variable. This analysis is based on sample size of 25 listed consumer food and services firms for 8-year period beginning from 2011 to 2018. Mean represents the average of the sample.

Based on the figure 1 above, the range of ROE is from 0.01847 to 1.22748 with mean value of 0.20814 and standard deviation is 0.22792 . The range of ROA is from 0.01508 to 0.52512 with the mean of 0.12418 and standard deviation of 0.08197 . Next, EPS has the mean value of 0.46175 and standard deviation of 0.68358 with range value from 0.0128 to 3.08334 . DPR ranges are from a minimum of 0.03117 to maximum of 3.15834 with the mean value of 0.6062 and standard deviation of 0.4015 while the PER shows the minimum of 0.0278 to a maximum of 52.4605. The mean value of PER is 12.9953 and the standard deviation of 8.99288.

Pearson Correlation Coefficient

Table 2: Pearson Correlation Coefficient

\begin{tabular}{|l|l|l|l|l|l|}
\hline & ROE & ROA & EPS & DPR & PER \\
\hline ROE & 1 & & & & \\
\hline ROA & $0.8568^{* * *}$ & 1 & & & \\
\hline EPS & $0.7559^{* * *}$ & $0.6461^{* * *}$ & 1 & & \\
\hline DPR & $0.3802^{* * *}$ & $0.3178^{* * *}$ & $0.2903^{* * *}$ & & \\
\hline PER & $0.4838^{* * *}$ & $0.2947^{* * *}$ & $0.3540^{* * *}$ & $0.4782^{* * *}$ & 1 \\
\hline
\end{tabular}

Note: $*, * *, * * *$ indicated respectively the significance at $10 \%, 5 \%$, and $1 \%$.

The table 2 shows the Pearson Correlation coefficient between all the dependent variable and independent variables which have been selected in the study. From the table above, the correlation between ROE and EPS is positive at 0.7559 and it is significant at $1 \%$ significant level while the ROE has positive correlation with DPR and significant at $1 \%$ 
significant level with value of 0.3802 . Besides, the correlation between ROE and PER is positive with figure of 0.4838 and it is significant at $1 \%$ significant level.

For the ROA model, the relationship between EPS and ROA is positive at 0.6461 and it is significant. DPR shows the positive correlation result with ROA at 0.3178 and it is found significant at $1 \%$ significant level. Furthermore, PER found the positive correlation with ROA and also significant at $1 \%$ significant level with value of 0.2947 . Independent variables for EPS in between EPS and PER are positive correlated with significant level of $1 \%$.

In a nutshell, the return on equity (ROE) is positive correlated with earning per share (EPS), dividend pay-out ratio (DPR) and price- earnings ratio (PER) which are $0.7559,0.3802$ and 0.4838 respectively. In addition, the return on asset (ROA) also positive correlated with earning per share (EPS), dividend pay-out ratio (DPR) and price-earnings ratio (PER) which are $0.6461,0.3178$ and 0.2947 . The value had shown that the independent variable correlated with dependent variable.

\section{Regression Model}

Table 3: Results of Panel Regression Model

\begin{tabular}{|c|c|c|c|c|c|c|}
\hline \multirow{3}{*}{ Variable } & \multicolumn{6}{|c|}{ Regression Model } \\
\hline & \multicolumn{2}{|l|}{ Pooled OLS } & \multicolumn{2}{|c|}{ Random Effects Model } & \multicolumn{2}{|c|}{ Fixed Effects Model } \\
\hline & ROE & ROA & ROE & ROA & ROE & ROA \\
\hline EPS & $\begin{array}{l}0.21869 \\
(0.000)^{* * *}\end{array}$ & $\begin{array}{l}0.07204 \\
(0.000)^{* * *}\end{array}$ & $\begin{array}{l}0.20830 \\
(0.000)^{* * *}\end{array}$ & $\begin{array}{l}0.09577 \\
(0.000)^{* * *}\end{array}$ & $\begin{array}{l}0.19069 \\
(0.000)^{* * *}\end{array}$ & $\begin{array}{l}0.10043 \\
(0.000)^{* * *}\end{array}$ \\
\hline DPR & $\begin{array}{l}0.05113 \\
(0.073) *\end{array}$ & $\begin{array}{l}0.02756 \\
(0.030)^{* *}\end{array}$ & $\begin{array}{l}0.00943 \\
(0.668) \\
\end{array}$ & $\begin{array}{l}0.00141 \\
(0.887) \\
\end{array}$ & $\begin{array}{l}0.00123 \\
(0.957) \\
\end{array}$ & $\begin{array}{l}0.00018 \\
(0.985) \\
\end{array}$ \\
\hline PER & $\begin{array}{l}0.00529 \\
(0.000)^{* * *}\end{array}$ & $\begin{array}{l}0.00016 \\
(0.782)\end{array}$ & $\begin{array}{l}0.00206 \\
(0.039) * *\end{array}$ & $\begin{array}{l}-0.00097 \\
(0.018) * *\end{array}$ & $\begin{array}{l}0.00159 \\
(0.120)\end{array}$ & $\begin{array}{l}-0.00103 \\
(0.014)^{* *}\end{array}$ \\
\hline $\mathbf{C}$ & $\begin{array}{l}0.00747 \\
(0.704)\end{array}$ & $\begin{array}{l}0.07214 \\
(0.000)^{* * *}\end{array}$ & $\begin{array}{l}0.07946 \\
(0.009)^{* * *}\end{array}$ & $\begin{array}{l}0.09175 \\
(0.000)^{* * *}\end{array}$ & $\begin{array}{l}0.09864 \\
(0.000)^{* * *}\end{array}$ & $\begin{array}{l}0.09108 \\
(0.000)^{* * *}\end{array}$ \\
\hline $\mathbf{R}^{2}$ & 0.6309 & 0.4362 & 0.6630 & 0.4002 & 0.6543 & 0.3975 \\
\hline $\begin{array}{l}\text { Adjusted } \\
\mathbf{R}^{2}\end{array}$ & 0.6253 & 0.4276 & 0.6578 & 0.3910 & 0.6490 & 0.3883 \\
\hline $\begin{array}{l}\text { Figure in } \\
* * *, * * \text { ar }\end{array}$ & rentheses $\mathrm{s}$ & ows p-value &.$\quad \ldots$ & evel. & & \\
\hline
\end{tabular}


This study is conducted by using panel data to determine the result in the study. There are three type of panel regression which included pooled ordinary least square, random effect model and fixed effects model. Different regression models provide different outcomes when investigating the relation between explanatory variables and dependent variables. Panel regression is employed in this study because panel data enables us to determine the heterogeneity of cross-section units over time, such as individuals, states, enterprises, and countries. It assists us in obtaining an unbiased estimate. In this study, the researcher will select the best model to be used to discuss the findings of the study.

The researcher had use Breusch Pagan LM test and Hausman test to choose the most suitable model. In this research, the Breusch Pagan test to use to see whether the pooled ordinary least square or random effect model is appropriate. Next, Hausman test was used to determine whether a fixed effect model or random effect model is preferable for this study. Lastly, the researcher will conclude which model is the best model to be used in this study. According to the rejection rule, the null hypothesis is rejected if the probability is less than the 5 percent significant level. Hence, the detail of both tests will be explained in the following section.

\section{Breusch Pagan LM test}

Table 4: Breusch Pagan LM test

\begin{tabular}{|l|l|l|}
\hline Model & Chi2 & Prob>chi2 \\
\hline ROE & 300.71 & 0.0000 \\
\hline ROA & 329.27 & 0.0000 \\
\hline
\end{tabular}

The Breusch pagan LM test is crucial because it helps to determine between the pooled ordinary least square (OLS) and random effect regression. Based on the rejection rule, null hypothesis is rejected if the p-value is less than 0.05 at 5 percent significance level. According to the table 4 above, the probability value is equals to 0.000 for both model which is less than 0.05 , there is statistical evidence to reject the null hypothesis. Hence, this shows that random effect regression model is suitable as compared to pooled ordinary least square (OLS).

\section{Hausman Test}

Table 5: Hausman test

\begin{tabular}{|l|l|l|}
\hline Model & Chi2(3) & Prob>chi2 \\
\hline ROE & 10.76 & 0.0131 \\
\hline ROA & 21.61 & 0.0001 \\
\hline
\end{tabular}

Table 5 shows the result from conducting Hausman test. In this research, Hausman test is conducted to select whether fixed effect regression or random effect regression more preferred in this study. According to the both model which are ROE and ROA, both $p$ value is less than significance of $5 \%$. Therefore, the null hypothesis is rejected which shows the random effect regression is not applied in this study. Hence, the fixed effect regression is applied in this study. 


\section{Diagnostic Test \\ Normality Test}

Table 6: Normality test

\begin{tabular}{|l|l|l|l|l|l|}
\hline Variable & Observation & $\begin{array}{l}\text { Pr } \\
\text { (Skewness) }\end{array}$ & $\begin{array}{l}\text { Pr } \\
\text { (Kurtosis) }\end{array}$ & Adj chi & Prob>chi2 \\
\hline myResiduals & 200 & 0.000 & 0.0000 & 38.57 & 0.0000 \\
\hline
\end{tabular}

The normality test determines whether or not the model is normally distributed. If the computed $p$-value is smaller than the $p$-value of $5 \%$ significance level, which $\alpha=0.05$, it will lead to the rejection of null hypothesis. This can be concluded that the data set are not normally distributed at $5 \%$ significance level. Based on the table above, the $p$-value of 0.0000 which is less than 0.05 at 5 percent significance level. Thus, null hypothesis is rejected. Therefore, this can be concluded that the model is not normally distributed.

\section{Multicollinearity}

Table 7: Multicollinearity Test

\begin{tabular}{|l|l|}
\hline Variables & VIF \\
\hline EPS & 1.39 \\
\hline DPR & 1.33 \\
\hline PER & 1.17 \\
\hline Mean VIF & 1.29 \\
\hline
\end{tabular}

Multicollinearity happen when two or more independent variables are highly correlate with another variable in the model. In this study, variance inflation factor (VIF) has been used to detect the multicollinearity. When the VIF is more than 10, it shows that the multicollinearity problem occurs in the model. In this study, the model has a mean VIF of 1.29, which has not exceeded the value of 10 , null hypothesis cannot be rejected. Hence, this can be concluded that multicollinearity does not exist in the model.

\section{Heteroskedasticity}

Table 8: Heteroskedasticity Test

\begin{tabular}{|l|l|l|}
\hline Model & Chi2(25) & Prob>chi2 \\
\hline ROE & 6026.74 & 0.0000 \\
\hline ROA & 9272.40 & 0.0000 \\
\hline
\end{tabular}

Heteroscedasticity occur when error term of variance different across observation. Modified Wald test is one of the tests for heteroskedasticity and it is chosen to examine whether the variance is all equal across the data. As presented on table 8 above, it clearly shows that the probability value of ROE model and ROA model is less than 0.05 at 5 percent significant level. Hence, the null hypothesis is rejected. This means that the variable used is not constant. Since the null hypothesis is rejected, it shows that heteroscedasticity exists in the model. 


\section{Autocorrelation}

Table 9: Autocorrelation Test

\begin{tabular}{|l|l|l|}
\hline Model & $\mathbf{F ( 1 , 2 4 )}$ & Prob>chi2 \\
\hline ROE & 6.939 & 0.0145 \\
\hline ROA & 13.033 & 0.0014 \\
\hline
\end{tabular}

Autocorrelation is used in this study in order to examine the error term from one period of time relies systematically on error term from other time period. Based on the table 9 , the obtained $p$ - value for each model is $p=0.0145$ and 0.0014 which is less than $5 \%$ level of significance. Therefore, the null hypothesis is rejected. Thus, it can be concluded that the autocorrelation exists in the model. Since the autocorrelation and heteroscedasticity problem exist, robust standard error will be used as remedial measure to eliminate the problem.

\section{Discussion}

Table 10: Fixed effect model with Robust Standard Error

\begin{tabular}{|l|l|l|}
\hline \multirow{2}{*}{ Variables } & Robust Fixed Effects Model \\
\cline { 2 - 3 } & ROE & ROA \\
\hline EPS & 0.19069 & 0.10043 \\
& $0.006^{* * *}$ & $0.000^{* * *}$ \\
\hline DPR & 0.00123 & 0.00018 \\
& 0.965 & 0.989 \\
\hline PER & 0.00159 & -0.00103 \\
& 0.356 & $0.062^{*}$ \\
\hline R-squared & 0.2811 & 0.4265 \\
\hline Adjusted R squared & 0.27 & 0.4177 \\
\hline F-test & 3.27 & 15.64 \\
& 0.0387 & 0.0000 \\
\hline
\end{tabular}

$* * *, * *$ and $*$ indicate $1 \%, 5 \%$ and $10 \%$ significant level.

In this study, fixed effect model is chosen and it is the most appropriate model as compare to another model. Based on the table 10, the result of $\mathrm{R}$ squared which measures the fitness of the model has a value of 0.2811 which indicates that $28.11 \%$ of the variations in the firm performance (ROE) are explained by the explanatory variables (EPS, DPR and PER), while about $71.89 \%$ of variations of the return on equity of the consumer goods firms are explained outside the unspecified variables such as error term. The adjusted $\mathrm{R}$ squared of 0.27 implies that there are about $27 \%$ of the total variation in return on equity explained by the explanatory variable. The F statistics $(0.0387)$ is less than $5 \%$ significance level which shows that the model is statistically fit to establish the relationship.

Based on the table 10, earning per share have a positively correlated with return on equity at 0.19069 and it is significant at $1 \%$. The coefficient shows that a 1 unit increase in earnings per share will resulted an increase of $0.19 \%$ in firm performance. This had shown that the higher the earning per share, the higher the performance of the company. This result is consistent with past researchers which are Khan (2018) and Hafeez, Shahbaz, Iftikhar and Butt (2018) who found that there was a significant positive relationship between earning per share and return on equity. 
Next, the dividend pay-out ratio is found to have positively associated with return on equity at 0.00123 and statistically insignificant at $1 \%$ significant level. The coefficient shows that a one unit increase in dividend pay-out ratio will lead to increase $0.00123 \%$ in firm performance. This also implies that the better the performance of the firm, the firm will likely be willing to pay dividend to their shareholders. However, the result of insignificant value indicates that any changes in dividend pay-out ratio has no effect on return on equity. According to Velnampy, Nimalthasan and Kalaiarasi (2014), it stated that the relationship between dividend pay-out ratio and return on equity is not significance. This result is consistent with Narang (2018); Musa et al. (2020); Ugwu, Onyeka and Okwa (2020); Cyril, Emeka and Cheluchi (2020) who found that there was a positive and insignificant between the variables.

Based on the empirical result, the researcher also found that the price earnings ratio has positive coefficient of 0.00159 which indicates that the relationship between price earnings ratio and return on equity is positive and insignificant at $1 \%$ level. The coefficient shows that one unit increase in earnings per share will increase $0.0016 \%$ in firm performance. Nevertheless, the insignificance result proved that any changes on earning per share will not impose any impact on ROA which it can be supported by Narang (2018) who found that the relationship between these two variables was insignificance. In addition, Priya and Nimalathasan (2013); Chauhan, Ansari, Taqi and Ajmal (2019) who also discovered that there was positive relationship between price earnings ratio and return on equity.

Besides that, in terms of return on assets, the coefficient of $R$ squared which measures the fitness of the model has a value of 0.4265 which indicates that there is about $42.65 \%$ of the variation in the dependent variable are explained by the explanatory variables (EPS, DPR and PER), while about $57.35 \%$ of variations of the firm return on asset of the consumer goods firms are explained outside the unspecified variables such as error term. The adjusted $R$ squared of 0.4177 implies that there are about $41.77 \%$ of the total variation in return on assets explained by the explanatory variable. The $F$ statistics $(0.000)$ is less than $5 \%$ significance level shows that the model is statistically fit to establish the relationship.

Based on table 10, earnings per share found the positive coefficient with return on asset at 0.10043 and it is significant at $1 \%$. The coefficient shows that one unit increase in earnings per share will increase $0.10 \%$ in firm performance. This finding can be supported by the previous researcher, Hafeez et al. (2018); Wijekoon (2019); Cyril et al. (2020) who also found that there is positive and significance connection between earning per share with the firm performance. This shows that when a company's financial performance is great, the earnings per share of its stockholders increases as well.

Dividend pay-out ratio has a coefficient of 0.00018 which indicates that there is a positive and insignificant relationship with return on asset. The coefficient shows that one unit increase in earnings per share will increase $0.00018 \%$ in firm performance. The result is supported by Paviththira (2015). However, this result was inconsistent with the study done by Velnampy et al (2014); Kajola et al (2015); Khan et al (2016); Cyril et al (2020); Musa et al (2020) as they found that the dividend pay-out ratio has negative and insignificance relationship with return on asset. Previous researchers indicates that negative coefficient shows that if the firm decided to pay the dividend, it would reduce the retained earnings of the firm which it would directly affect the internal financing.

Price-earnings ratio has a coefficient of -0.00103 which indicates that there is a negative and significant relationship with return on asset. The coefficient shows that a one unit increase in earnings per share will decrease $0.001 \%$ in firm performance. This result 
indicates that when the price earnings ratio of the firm is increase, it can be seen that the firm does not use its asset efficient in term to increase their revenue which remarkably supported by the research done by Priya and Nimalathasan (2013) who found that the price earnings ratio is significantly negative correlated with the return on asset. Supposedly, the expected results for this should shows a positive significantly affect which proven by Hafeez et al (2018); Chauhan et al (2019) who found that there was significant positive relationship between the variables.

\section{Conclusion}

The main objective of this study is to investigate the relationship between the dividend policy on firm performance. The independent variables used in the study was earnings per share (EPS), dividend pay-out ratio (DPR) and price earnings ratio (PER) whereby the dependent variables are return on equity (ROE) and return on asset (ROA). In this study, a total of 200 observations made and the data was adopted from 25 public listed firms on consumer product and services industry which were selected randomly from Bursa Malaysia throughout the period of the year 2011 to the year 2018. Besides, secondary data was employed to obtain the firms information and results. In this research, fixed effect model was chosen as the best model. The researcher found that heteroskedasticity and autocorrelation problem exists in the model and had used robust standard error to solve the problem. Therefore, the findings of the research were all based on the fixed effect model with robust standard error.

According to the findings, EPS shows a significant positive relationship with return on equity. DPR has an insignificant positive relationship with ROE. It indicated that there is no impact on DPR and ROE which shows that the increase in DPR will not affect the return on equity. For PER, the positive and insignificant relationship was found based on the result obtained from the model. This suggested that the increase of the PER will not lead to an impact on the ROE of the firms. In addition, in the model of ROA, the findings found that there was significantly positive relationship between EPS and ROA. DPR has an insignificant positive relationship with ROA while PER showed a negative and significant relationship with ROA.

In a nutshell, as in Malaysia, Bursa Malaysia does not set any standard rules and regulations for the dividend payment of firms in every industry. The firms in Malaysia have the freedom on deciding their own dividend pay-out rate to the shareholders. Therefore, it is important for the management of the firms to determine how much they willing to pay and when to distribute the dividend payment among their shareholders. For the firms that does not distribute all profits as dividends, they much prefer to reinvest or pay off their debts from the retained earnings as having a dividend policy in the firms does give huge changes on the firm's future performances. This is because when there is an increase or decrease in the dividend payment, it will also affect the fluctuation on the stock prices of the firms. Based on the finding, the earning per share found that it is significant with the firm performance which means that it does influence the value of the consumer product and service firms. The value of consumer product and service firm is very essential information to the investors as it is one of the indicators for them on making the decision whether proceed on their investment towards the firms. Basically, when the investors plan to invest on a firm, they would study and do research on the firm that manage to spark their interests in detail to avoid any loss from their investment. Apart from that, earning per share also indicates the abilities of the consumer product and service firm to pay dividend to their shareholders. Henceforth, firms 
should take cautions on taking debts because it will affect the payment of dividend as well as this would become the indicator for the investors whether to invest or not.

\section{Limitation of Study}

Same as the other empirical studies, every researcher will encounter with their own problem as their own limitation when conducting the research, this study is also not exempted from that. The limitation does affect the findings of the study. This might cause the findings of the future research will be inconsistent with the findings of this study. Data availability is one of the limitations of this study. Besides, some of the firms' annual report does not provide the details about the dividend. The total periods of this study was 8 years which might not enough to obtain more accurate results as the longer the time frame, it will give more accurate or relevant results and findings. Moreover, as the sample of this research are limited to one sector which is consumer product and services sector. Therefore, it indicates that the results or the findings of this study might not be suitable for all of the industries. Furthermore, this study only focuses on Malaysia which lead to the findings might be only suitable to use for the policy makers in Malaysia as well as investors. Last but not least, the techniques employed to conduct the research would also causes the finding of this study to be different from the previous scholars.

\section{Suggestion for Future Study}

For the recommendation to future researcher who wish to carry out the study on the impact of dividend policy on firm performance in Public listed companies in Malaysia, the suggestion will be encouraged to increase the periods of the sample. Future researcher can increase the sample size by including more sectors that are listed in Bursa Malaysia. Besides, future researcher can add other variables in order to determine which variables give more impacts to the firm performance. Variables such as Tobin-q shall be employed to measure the firm performance and add other measurement of dividend policy such as dividend per share and price to book value to make the research become more useful. Other than that, it is best to add a control variable for future study as this study does not include any control variable. Another suggestion for future researcher is that they could employ other model to conduct the research. Different model such as logistic model which would give different outcomes. By employing other models in the study, it can provide the research clearer vision and have better understanding which related on dividend policy on firm performance. Apart from that, if the target of future researcher is at Malaysia, it is recommended to review the journal articles that based on Malaysia as compared to foreign countries because different countries have different cultures and lifestyle. In addition, future research should plan their time wisely during conduct the study because to have good research, a researcher has to spend more time on it. It is the important process as researcher need time to read more information and research paper in order to get accurate details. Not only that, the researcher should also recheck their results at least twice to ensure there is no mistake occurs.

\section{Acknowledgement}

I would like to express my gratitude to Madam Nurul Izza binti Abd Malek for her guidance and support Besides, I also would like thank to Faculty Economics and Business in University Malaysia Sarawak for the support. 


\section{References}

Ajanthan, A. (2013). The relationship between dividend payout and firm profitability: a study of listed hotels and restaurant companies in Sri Lanka, International Journal of Scientific and Research Publications, 3(6), 2250-3153.

Al Shabibi, B. K., \& Ramesh, G. (2011). An empirical study on the determinants of dividend policy in the UK. International Research Journal of Finance and Economics 80, 105-120.

Allen, D., \& Rachim, V. (1996). Dividend policy and stock price volatility: Australian evidence. Applied Financial Economics, 6(2), 175-188.

Amidu, M. (2007). How does dividend policy affect performance of the firm on Ghana stock exchange? Investment Management and Financial Innovations, 4(2), 103-112.

Anandasayanan, S., \& Velnampy, T. (2016). Dividend policy and corporate profitability econometric analysis of listed manufacturing firms in Sri Lanka. International Journal of Commerce and Management Research, 2(1), 53-58.

Azhagaiah, R., \& Priya, N.S. (2008) The impact of dividend policy on shareholders' wealth. International Research Journal of Finance and Economics, 20, 180-187.

Baker, H., and Powell, G. (2000). Determinants of corporate dividend policy: a survey of NYSE firms. Financial practice and education, 10 (29), 1082-0698.

Black, J. (1976). The Dividend Puzzle. Journal of Portfolio Management, 2, 5-8.

Brealey, R., \& Myers, S. (2005) Principles of Corporate Finance. 8th Edition, McGraw-Hill, London.

Chaabouni, I. (2017). Impact of dividend announcement on stock return: a study on listed companies in the Saudi Arabia financial markets. International Journal of Information, Business and Management, 9(1), 37.

Chauhan, J., Ansari, M. S., Taqi, M., \& Ajmal, M. (2019). Dividend policy and its impact on performance of Indian Information Technology Companies. International Journal of Finance and Accounting, 8 (1),36-42.

Cyril, U. M., Emeka, E. C., \& Cheluchi, I. F. (2020). Effect of dividend policy on financial performance of consumer goods manufacturing Firms in Nigeria. Science Journal of Business and Management, 8 (1),7-15.

Duke, S. B., Ikenna, N. D., \& Nkamare, S. E. (2015). Impact of dividend policy on share price valuation in Nigerian Banks. Archieve of Business Research, 3(1), 156-170.

Ekene, I., Celestine, O., \& Ejiogu. (2019). Effect of dividend policy on shareholders' value: evidence from consumer goods firms quoted in Nigerian Stock Exchange. Journal of Banking and Finance, 3(3), 405-413.

Farrukh, K., Irshad, S., Khakwani, M. S., \& Ishaque, S. (2017). Impact of dividend policy on shareholders wealth and firm performance in Pakistan. Cogent Business \& Management, 4(1), 2331-1975.

Fernando, J. (2020, November 13). Dividend yield. Investopodia. Retrieved November 5,2020, from https://www.investopedia.com/terms/d/dividendyield.asp

Gordon, M, J. (1963). Optimal investment and financing policy. Journal of finance, 18, 264272.

Gunasekarage, A., \& Power, D. M. (2006). Anomalous evidence in dividend announcement effect. Managerial Finance, 32(3), 209-226.

Hafeez, A., \& Attiya, Y. J. (2009). The determinants of dividend policy in Pakistan, International Research Journal of Finance Economics, 25, 148-171. 
Hafeez, M. M., Shahbaz, S., Iftikhar, I., \& Butt, H. A. (2018). Impact of dividend policy on firm performance. International Journal of Advance Study and Research Work 1(4), 25815997.

Jensen, M. C., \& Meckling, W. H. (1976). Theory of the firm: Managerial behavior, agency costs and ownership structure. Journal of financial economics, 3(4), 305-360.

Kajola, S., Adewumi, A., \& Oworu, O. (2015). Dividend pay-out policy and firm financial performance: evidence from Nigerian listed non-financial firms, International Journal of Economics, Commerce and Management, 3(4).

Kanakriyah, R. (2020, September 6). Dividend policy and companies' financial performance. Journal of Asian Finance, Economics and Businesses, 7(10), 531-541.

Khan, A. W. (2018). Effect of dividend policy on firm's performance: case study of cement sector of Pakistan. Journal of Management 1(5), 6-15.

Khan, M. N., Nadeem, B., Islam,F., Salman,M., \& Gill, H. M. I. S. (2016). Impact of dividend policy on firm performance: an empirical evidence from Pakistan Stock Exchange. American Journal of Economics, Finance and Management 2(4), 28-34.

Lai, T. K. (2016). The impact of dividend policy on firm performance in consumer product and trading/services sector in Malaysia. International Journal for Research in Business, Management and Accounting 2(2), 90-103.

Mat, N. C., Mokhtar, N. A., Ali, S., Kaisim, K., \& Zani, R. M. (2017). The determinants of dividend policy of public listed companies in Malaysia. Journal of Humanities, Language, Culture and Business (HLCB) 1(4), 36-47.

May, M. G., \& Yacob, N. (2018). The influences of company's size and past year's dividend information to public listed companies in Malaysia. Taylor Business Review 7 (1), 63-81.

Miller, M., \& Modigliani, F. (1961). Dividend policy, growth, and the valuation of shares. Journal of Business, 34, 411-433.

Musa, F., Ibrahim, A., \& Garba, M. (2020). Dividend policy and financial performance of consumer goods companies in Nigeria. International Journal of Research in Commerce and Management Studies, 2(2), 2582-2292.

Nabi, A. A. (2014). Earnings per share impact on non-financial firms' performance. Journal of Economic Info 1(4), 1-7.

Narang, M. (2018). Dividend policy and firm performance: A study of listed firms on national stock exchange. International Journal of Advanced Educational Research 3(1), 286-289.

Nissim, D., \& Ziv, D. (2001) Dividend changes and future profitability. Journal of Finance, 56 (6), 2111-2133.

Nwabuisi, N. A., \& Aseoluwa, A. C. N. (2017). Dividend payout ratio and share price: Evidence from quoted manufacturing companies in Nigeria. Journal of Business and Management 9(10), 30-43.

Ogbuagu, N. M. (2020). Effect of dividend policy on firm's performance. Journal accounting, business and social sciences 3(2), 2672-4235.

Pandey, I. M. (2003). Corporate dividend policy and behaviour: the Malaysian evidence. Asian Academy of Management Journal, 8(1), 17-32.

Paviththira, R. (2015). Impact of dividend policy on corporate profitability: evidence from listed beverage food and tobacco companies on Colombo Stock Exchange (CSE) in Sri Lanka. Proceedings of 12th International Conference on Business Management.

Priya, K., \& Nimalathasan. (2013). Dividend policy ratios and firm performance: a case study of selected hotels \& restaurants in Sri Lanka. Global Journal of Commerce and management perspective 2(6), 16-22. 
Subramaniam, R., \& Devi, S. S. (2010). Corporate governance and dividend policy in Malaysia. International Conference on Business and Economics Research, 1, 200- 207.

Ugwu, C. C., Onyeka, V. N., and Okwa, I. E. (2020), Dividend policy and corporate financial performance: evidence from selected listed consumer goods firms in Nigeria. Journal of Economics and Business, 3 (3), 1055-1065.

Uwuigbe, U., Jafaru, J., \& Ajayi, A. (2012). Dividend policy and firm performance: a study of listed firms in Nigeria. Accounting and Management Information Systems, 1 (3), $442-$ 454.

Velnampy, T., Nimalthasan, P., \& Kalaiarasi, K (2014). Dividend policy and firm performance: evidence from the manufacturing companies listed on the Colombo Stock Exchange. Global Journal of Management and Business Research 14(6), 2249-4588.

Wijekoon, S. (2018). Impact of dividend policy on firm performance evidence from listed companies in Colombo Stock Exchange. Global Scientific Journals, 7(10), 2320-9186.

Wong, M. N. (2012) Determinant of dividend policy: evidence from Sarawak public listed companies. Master's thesis, University Malaysia Sarawak, UNIMAS.

Yusof, Y., \& Ismail, S. (2016). Determinants of dividend policy of public listed companies in Malaysia. Review of International Business and Strategy, 26(1), 88. 